\title{
The Place and Importance of Propolis in Cancer Immunotherapy
}

\author{
Propolisin Kanser İmmünoterapisindeki Yeri ve Önemi
}

(i) Nigahban İPEK, id Berna PINARBAŞI, id Ayşe GÜNEŞ BAYIR

Bezmialem Vakıf University Faculty of Health Sciences, Department of Nutrition and Dietetics, İstanbul, Turkey

\section{ABSTRACT}

Nowadays, the increasing number of cancer patients is a major concern all over the world. Therefore, finding safe and effective treatments has become one of the main goals of researchers. Immunotherapy is a form of treatment that allows the individual to fight against many diseases including cancer by using the immune system. The aim is to enable cells of the immune system to target and destroy cancer cells. Immunotherapeutic strategies in cancer are spread to a wide range of research areas including monoclonal antibodies, cancer vaccines, adoptive immunotherapy, cytokines, and immune system enhancing drugs. Due to the specificity of the immune response in new treatment methods, it is aimed that the immunity against the tumor is to destroy the tumor selectively without harming the patient. In recent scientific studies, it has been revealed that propolis is one of the most promising immunomodulating agents. Propolis is a natural medicine that widely used since ancient times and contains several bioactive compounds. More than 300 components of propolis have been identified to date and in vitro, in vivo and clinical studies of these components are ongoing. The major anticancer components in propolis are Convective available potential energy, chrysin, nemorosone, artepilin $\mathrm{C}$, galangin and cardanol. The in vitro, in vivo and human clinical researches report that the propolis shows positive effect against the several different cancer types. Propolis as a natural food with these properties may support the immune system and body function of cancer patients.

Keywords: Cancer, Immunotherapy, cancer immunotherapy, propolis

\section{ÖZ}

Günümüzde gittikçe artan kanser olguları, tüm dünyada büyük bir endişe kaynağı olmaktadır. Bu nedenle; güvenli ve etkili tedaviler bulmak araştırmacıların ana hedeflerinden biri haline gelmiştir. İmmünoterapi; bireyin bağışıklık sistemini kullanarak kanser dahil çok sayıda hastalıkla mücadele etmesini sağlayan bir tedavi biçimidir. Amaç, immün sisteme ait hücrelerin kanser hücrelerini hedef almalarını ve yok etmelerini sağlamaktır. Kanserde immünoterapötik stratejiler; monoklonal antikorlar, kanser aşıları, adoptif immünoterapi, sitokinler, immün sistemi destekleyici ilaçlar da dahil olmak üzere geniş bir araştırma alanına yayılmaktadır. Yeni tedavi yöntemlerinde immün yanıtın özgül olması nedeniyle tümöre karşı bağışıklığın, hastaya zarar vermeden seçici olarak tümörü yok etmesi amaçlanmaktadır. Son yapılan bilimsel araştırmalarda propolisin güçlü bir şekilde en umut verici immünomodülasyon ajanlarından biri olduğu ortaya konmuştur. Propolis, antik çağlardan beri yaygın olarak kullanılan ve bünyesinde birçok biyoaktif bileşen barındıran doğal bir ilaçtır. Propolisin 300'den fazla bileşeni bugüne kadar tespit edilmiş olup bu bileşenlerle ilgili in vitro, in vivo ve klinik çalışmalar devam etmektedir. Propolisin içindeki başlıca antikanser bileşenler; Convective available potential energy, chrysin, nemoroson, artepilin C, galangin ve kardanoldür. Propolisin birçok farklı kanser türüne karşı olumlu etki gösterdiği in vitro ve in vivo olarak ve insan klinik çalışmalarıyla bildirilmiştir. Doğal bir besin olan propolisin tüm bu özellikleri ile kanser hastalarının vücut fonksiyonlarını ve hastaların vücut direncini destekleyebileceği düşünülmektedir.

Anahtar Sözcükler: Kanser, immünoterapi, kanser immünoterapisi, propolis

Address for Correspondence: Ayşe GÜNEŞ BAYIR, Bezmialem Vakıf University Faculty of Health Sciences,

Phone: +90 2124531700 E-mail: agunes@bezmialem.edu.tr ORCID ID: orcid.org/0000-0002-9993-7850

Cite this article as: İpek N, Pınarbaşı B, Güneş Bayır A. The Place and Importance of Propolis in Cancer Immunotherapy. Bezmialem Science 2022;10(1):123-0 


\section{Introduction}

Millions of people are diagnosed as having cancer every year in the world and more than half of these patients die due to cancer. Despite all scientific advances, cancer is a process in which there are many difficulties for patients throughout the treatment that develops from its diagnosis (1). On the other hand; this situation causes great concern in societies. For all these reasons, safe and effective anticancer treatment researches are still continuing today. As a result of these researches; a method called immunotherapy, which aims to use the power of the body's own immune system against cancer, has also been introduced (2). In the last decade, the successful clinical use of immunotherapeutic agents in cancer treatment has increased the interest in tumor immunology and in the use of immunotherapy with high response rates in tumors including solid tumors. Cancer immunotherapy includes the processes of using and/or activating components of the immune system such as antibodies, dendritic cells and T-lymphocytes to treat cancer (3). Target in cancer treatment is the complete elimination of the disease or the prolongation of life expectancy (1). Immunotherapy is thought to be a more effective and durable form of treatment than conventional treatments for cancer by using the body's own immune system (4). Today, studies on the contribution of naturally occurring plant and/or animal origin products and foods to the treatment process of cancer are important (5). For example, it has been reported in studies that bee products may have the potential to be used in cancer immunotherapy thanks to their immunomodulatory effects, as well as their antiinvasive and antitumor effects. Propolis, which is an important bee product, contains important phenolic compounds such as gallic acid, catechin, caffeic acid, quercetin, cinnamic acid, naringenin, apigenin, galangin and caffeic acid phenyl ester (CAPE). Studies have proven the anticancer, antiproliferative and anti-inflammatory effects of propolis and new studies are continuing. In this review, the state of the immune system in cancer patients, the ways and mechanisms of cancer in suppressing the immune system, the effects and side effects of immunotherapeutic methods that are frequently used in cancer treatment, and the anticancer effects of propolis with immunotherapeutic mechanisms were presented with scientific data. In this context, in vitro, in vivo and clinical human studies were also considered.

\section{Cancer}

\section{What is Cancer?}

Cancer is the clonal spread of cells with impaired growth characteristics, which is known as the most common and the most complicated somatic genetic disease (6). All cancers, as a result of successive mutations in the DNA sequence, can cause the cell to grow and the formation of a cancer clone derived from this cell (7).

\section{Cancer and the Genome}

With exposure to mutagens and carcinogens, fractures occur in the genetic material of the cell (7). The genotoxic effect of mutagenic and carcinogenic compounds can be determined by detecting DNA breaks (damage). This genotoxic effect, which is also defined as DNA damage, is accepted as a cancer-initiating mechanism. Cancer differs depending on the cell of origin and the spectrum that promotes genomic changes, which also affect the therapeutic response (8). However, it is a known fact that all cancer types are basically a genomic disease (9).

\section{Cancer Treatments and Ways of Prevention}

At the end of the $20^{\text {th }}$ century, animal cancer models were used to develop drugs necessary for the treatment of cancers (9). These studies have led to the development of adjuvant chemotherapy studies and the creation of cancer guidelines. It is known that environmental factors and positive dietary habits are also very important in the prevention of cancers (10).

\section{Immune System}

The immune system is a collection of organs, special cells and substances that protect the individual from infections and other diseases. It also helps to protect the person from cancer (11). The immune system, which consists of lymph vessels, lymph nodes, bone marrow, thymus, spleen, tonsils, organs, tissues and white blood cells of the lymph system, detects a large number of threats and prevents these threats from distrupting homeostasis (12). Immune system cells and the substances they produce show their effects by circulating the body. The immune system monitors all substances in the body. When it encounters any foreign substance, it receives an alarm that causes it to attack and responds to protect and defend the body $(11,13)$. This foreign substance can be an infectious agent or a tumor cell.

\section{The Immune System in Cancer}

The detection and destruction of tumor cells formed in the body by the immune system is called immune surveillance. The existence of immune surveillance has been known since the early 1900's (13). However, despite the presence of immune surveillance, the ability of the immune system to fight cancer on its own is limited, and therefore cancer develops despite all mechanisms. The immune system does not always recognize cancer cells as foreign. The reason for this is that cancer cells undergo changes, are not sufficiently different from normal cells, and go out of control (11). Sometimes the immune system can recognize cancer cells, but immune responses often fail to prevent tumor growth $(11,13)$. Cancer cells can also produce some substances that keep the immune system under control (11).

\section{Immune Surveillance of Cancer}

The functions of the immune system to prevent the growth of transformed cells or to destroy them before they become harmful are called "cancer immunosurveillance" (14). Immune surveillance is possible only when the tumor begins to carry cell surface antigens that can be defined as foreign by the immune system (13).

\section{Immune Control of Cancer}

Tumor cells go through three stages before they become clinically noticeable. The development of tumors in humans despite 
immune surveillance is tried to be explained by the " $3 \mathrm{E}$ " theory of immune editing (Figure 1). These three phases are "Elimination", "Equlibrium" and "Escape". Although the immune system tries to prevent the survival of cancer cells during these three stages, it is ineffective in the elimination of some cancer cells (13). The immune surveillance of the host is suppressed and malignant cells emerge in this way (14).

The efforts of the immune system to prevent the formation of cancer lead to various consequences such as the ability to completely prevent the formation of some tumors, to remain unprotected in some tumors, and the formation of immunological anergy or tolerance $(14,15)$.

\section{Elimination}

The immune system first attacks tumor cells with polymorphic leukocytes, natural killer cells (NK), and monocytes/ macrophages. Pro-inflammatory cytokines released and tumorrelated peptide sequences prepared and presented by monocytes/ macrophages and dendritic cells activate $\mathrm{T}$ - and B-cells of the cellular/adaptive immune system. The release of interferongamma (IFN- $\gamma$ ), which is very important among cytokines, increases the migration of immune system cells to the tumor site, and induces apoptosis by showing cytotoxic effects with its antiproliferative and anti-angiogenic effects (13). With its apoptotic and antiproliferative effects, IFN- $\gamma$ causes death of tumor cells to a limited extent and induces the release of chemokines from tumor cells and surrounding normal tissues. These chemokines, which have angiostatic effects, cause the elimination of more tumor cells by stopping the formation of new vessels around the tumor (14). DC and macrophages infiltrating the tumor provide NK activation with the release of interleukin 12 (IL-12) and IFN- $\gamma$, and perforin causes more tumor cells to die through tumor necrosis factor (TNF)-related apoptosis-inducing ligand and reactive oxygen formation mechanisms. With the cytokines they secrete, CD4+ T-cells help B-lymphocytes to turn into plasma cells and secrete antibodies, NK and CD8+ T-lymphocytes to become more activated and thus to eliminate tumor cells (13). NK and CD8+ T-lymphocytes undertake the final task in tumor immunity, and if successful, tumor cells are destroyed (13-15).

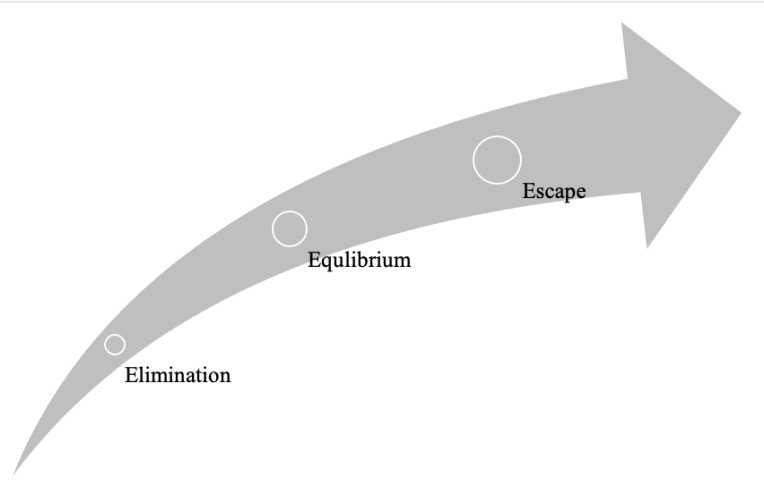

Figure 1. The "3E" theory of immunoediting

\section{Equlibrium}

Despite all these eradication efforts against the tumor, genetic/ environmental or unknown microbial factors that are effective in tumor formation may cause genetic instability to continue and new methods to be produced against immune system defense mechanisms (13). Lymphocytes and IFN- $\gamma$ exert a potent selection pressure on tumor cells that genetically mutate rapidly. In the meantime, many tumor cells that have undergone variation are destroyed, but there are also variants that show new mutations that are much more resistant to immune attacks. It is thought that this phase is the longest among the three phases and it takes years (14).

\section{Escape}

The escape phase indicates the formation of immunological tolerance, which means immunologically non-recognition and/or non-response. Genetic or epigenetic changes in the tumor cause the tumor to resemble normal body cells and escape from the immune system. In order to escape from CD4+ T-lymphocytes, tumor cells reduce the formation of tumor antigens or their surface expression, which is responsible for antigen presentation. Another method used by tumors is to secrete factors that bind pro-inflammatory cytokines and prevent them from functioning (13). All these mechanisms cause the body to be completely defenseless (13-15). Tumor variants become insensitive to immunological detection and proliferate uncontrollably. As a result, clinically observable malignant disease occurs and if untreated, it causes death of the host. To overcome these, ways such as immunotherapy have been found to help the immune system recognize cancer cells and strengthen its response (11).

\section{Cancer Immunotherapy}

Immunotherapy is a form of treatment in which parts of the individual's immune system are used to fight a certain group of diseases, including cancer. The aim is to enable cells of the immune system to target and destroy cancer cells (16). When the innate immune system is stimulated, tumor antigens released from the tumor are recognized and some T-cells stimulated by the immune system capture and destroy the tumor cells. Other T-cells, on the other hand, stimulate B-cells, which are other cells of the immune system, and these cells turn into antibodyproducing plasma cells (17). The main strategy aims to provide patients with antitumor effectors (antibodies and T-cells), stimulating the patient's own antitumor response. Tumors develop mechanisms that enhance their survival (eg, Bcl-2 expression) and immunoregulatory molecules (eg, programmed cell death-1 (PD1), PD-1 ligand (PD-L1), cytotoxic T-lymphocyte-associated protein- 4 (CTLA-4) inhibitors of immune checkpoints) can evade the immune response (18). The presence of identifiable tumor antigens in most of the tumor cells and the inability of the immune system to prevent tumor growth led to the formation of immunotherapy. The use of methods such as the production of antigen-specific T-lymphocytes and antibodies targeting tumor antigens, identification and purification of tumor antigens with the latest developments in technology has revealed the idea 
that tumors can be destroyed by immunotherapy. In addition, lymphocyte isolation and increasing the efficiency of the immune system with cytokines also supported immunotherapy (14). Tumors can evade the immune response by developing mechanisms that enhance their survival (eg, Bcl-2 expression), and by expressing immunoregulatory molecules [eg, immune checkpoints inhibitors such as programmed cell death-1 (PD-1), PD-1 ligand (PD-L1) and CTLA-4] (18).

Various side effects are seen depending on the treatment method used in cancer treatment, the chemotherapeutic agent used, and the dose of chemotherapy and/or radiotherapy (17). Because new treatment modalities affect the immune response, it is aimed that tumor-specific immunity will selectively destroy the tumor without harming the patient. It is possible to interfere with the immune system with immunotherapy in order to regulate the immune response and to achieve tumor eradication despite the escape of tumors from the immune system (14).

\section{Treatment Methods Used in Cancer Immunotherapy}

\section{Monoclonal Antibodies}

It is a treatment method that ensures that cancer cells circulating in the body and carrying antigens are destroyed by other parts of the immune system until monoclonal antibodies find and neutralize the foreign protein (17).

\section{Cancer Vaccines}

Cancer vaccines have been produced to induce tumor-specific immune responses, particularly cytotoxic CD8-positive T-cells specific for tumor antigens. These vaccines help in cancer treatment or prevent the recurrence of cancer after other treatments (19). The patient can be vaccinated with his own tumor cells or tumor antigens. Vaccines can be given as recombinant proteins with adjuvants to increase the immune response (14). Cancer vaccines enable the immune system to attack tumor cells containing one or more specific antigens. Since memory cells are effective in the immune system, it is hoped that the vaccine will continue to work long after it is given (19).

\section{Adaptive Immunotherapy}

In this treatment, tumor-specific cytotoxic T-cells are given to cancer patients for the purpose of recognizing, targeting and destroying tumor cells. T-cells are harvested from a patient's blood or tumor site, then stimulated to grow and expand in an in vitro culture system. After sufficient in vitro growth, these cells are reinjected into the host, thereby causing tumor destruction (20).

\section{Cytokines}

With the use of cytokines, it is aimed to optimize the response after the patient creates an immune response (14).

\section{Nutritional Supplements with Immunodilator and Anticancer Effects}

Apart from the reported immunotherapy treatments; components of nutrients such as black cumin, turmeric, soy products, cinnamon and garlic (thymoquinone, curcumin, genistein, p-coumaric acid and allicin, respectively) can reduce the effectiveness of cancer cells and increase the effectiveness of some cancer drugs $(21,22)$. Ginseng (Panax ginseng, Korean ginseng) prevents drug resistance and increases the recognition of tumor cells (21). Polysaccharopeptides (edible mushrooms) help prevent the vascularization of cancer cells and regulate the immune system (21). Also; some betaglucans such as lentinan with polysaccharide structure found in fungi have been shown to stimulate macrophages, NK cells, T-cells and cytokines. Researches continue in this area. Agaricus subrufescens, Lentinula odedes, Grifola frundosa and Hericium erinaceus are known to have these properties (23). Adequate selenium intake (200-400 $\mu \mathrm{g} / \mathrm{day})$, beta carotene, zinc and fungal polysaccharides can stimulate NK cells (21).

\section{Side Effects of Cancer Immunotherapy}

The side effects of immunotherapies are caused by immunemediated damage to normal tissues. These damages are due to the changes in the interactions between cancer cells and the immune system due to the treatments. The skin and mucosa, luminal gastrointestinal system, liver and endocrine system are the most frequently affected organs and systems. Skin rashes are usually the earliest side effect. There may be erythematous, reticular or maculopapular skin rashes. Mucositis may occur with dry mouth (18).

\section{Propolis}

\section{What is Propolis?}

Propolis is a resinous substance collected by honey bees from leaf buds and cracks (24). Honey bees form propolis by mixing the $\beta$-glucosidase enzyme found in their salivary secretions and partially digested wax into the resin they collect. Apis Mellifera honey bees living around Europe, the Ural Mountains, Africa and Asia play a role in the production of propolis (25). Propolis is a natural medicine that has been widely used since ancient times (26). The use of propolis in folk medicine is dated to 300 BC. Positive anticancer, antioxidant, anti-inflammatory, antibiotic, antifungal and antihepatotoxic effects have been demonstrated in studies. Propolis is a substance widely used in foods to promote health and prevent health problems such as inflammation, diabetes, cancer and cardiovascular diseases (27). Research against the composition and biological activities of propolis is still ongoing. More than 300 components of propolis have been identified to date (28). Propolis has anti-bacterial, anti-fungal, anti-viral, anti-tumor, hepatoprotective, antiinflammatory effects. In addition to these features, it has been used as a part of traditional medicine since ancient times, as it naturally increases the body's resistance to infections and treats gastroduodenal ulcers (26).

\section{Chemical Structure of Propolis}

Many studies have been done on the structure and chemical properties of propolis, and hundreds of chemical compounds have been identified in propolis. However, there is no chemical standardization of propolis based on active principles (29). The 
positive effects of propolis on health have been demonstrated in many in vivo and in vitro experimental studies. In particular, the polyphenols in its content prevent many specific diseases and prevent the progression of diseases.

It acts through various mechanisms (22). Phenolic and aromatic compounds such as flavonoids show the most important pharmaceutical and biological activity in propolis. The flavonoid and phenolic compounds of propolis are known as the most active substances with anticancer effect. Propolis inhibits the growth of tumor cells. Its cytotoxic effect is associated with different activities of different propolis types (30).

\section{Uses of Propolis}

Propolis collected from the hive is obtained as raw and must be used after being purified. Especially; since some allergic reactions may occur due to its composition in its medicinal use, propolis should be produced under the necessary controls, presented and used after processing (31). There are great differences in the compositions of propolis samples taken from different geographical regions. However; it is observed that all samples have antibacterial, antiviral and antifungal activity in common. These activities of propolis are related to the use of propolis by bees as a defense against infections (32). Propolis is a versatile substance used in apitherapy centers, in the food industry, in the pharmaceutical and cosmetic industry due to its antibacterial and antioxidant effects and the chemicals it contains (33).

Thanks to the rich vegetation of our country, Turkish propolis contains a wide variety of compounds (5). Turkish propolis is especially rich in polyphenolic compounds such as pinocembrin, isalpine, pinotropin, naringenin, quercetin, chrysin, galangin, pinobanksin, apigenin, 3,40, 7-trimethoxy flavanone and caffeic acid (34). In a study examining the in vitro effects of Turkish propolis on lung cancer; it was found that the ethanolic extract of propolis had a pro-apoptotic effect by reducing the mitochondrial membrane potential of A549 cells and inducing caspase activity (35). The bioactivity of propolis develops depending on the variety and concentrations of the compounds contained in propolis.

\section{Immunological Effects of Propolis}

In recent scientific research, propolis is thought to be one of the substances with a strong immunomodulating effect. This aspect of propolis needs to be supported by exploratory studies including more clinical trials. Propolis can be considered as a complementary therapy due to its immunomodulatory effects and can be seen as an alternative therapy in immune disorders (36). The antitumor effect of propolis and its components has been found to be associated with regulating the immune system through macrophage activation (37).

\section{Immunotherapeutic Effects of Propolis in Cancer}

Propolis is used in medicine as a treatment for cancer and immune diseases (38). Propolis has biological activities such as antibacterial, antifungal, antiviral, antioxidant, anti- inflammatory, cytotoxic, immunomodulatory, local anesthetic, antiulcer, antitumor and immunostimulatory effects (39). Flavonoids, aromatic acids and their esters are thought to be the compounds responsible for the biological activity of propolis (33). Effective antitumor components in propolis are known as CAPE, chrysin, nemoroson, artepilin C, galangin and cardanol (40). The anticancer effect of propolis is the result of its antioxidant, antiinflammatory, immunomodulatory, cytostatic, antineoplastic features, suppression of proliferation in cancer cells, reduction of cancer stem cells and populations, inhibition of specific oncogene signaling pathways, providing anti-angiogenesis, modulating the tumor microenvironment and increasing chemotherapeutic activity $(40,41)$. Also, propolis seems to alleviate the side effects caused by drugs (41). Stimulating effects of propolis on antibody production and lytic activity of NK cells against tumors have been demonstrated (42). Propolis creates resistance against various pathogens and tumor cells by affecting macrophage functions, lymphocyte proliferation and plaque-forming cells in the spleen (43).

It has been observed that water-soluble derivatives of propolis increase the immunomodulatory capacity. Propolis provides stimulation and induction of lymphocytes and some cytokines and affects IL-1 and TNF. Propolis injection in mice showed complementary activity in humoral immunity (44). It was observed that in vivo application of water-soluble propolis extract (WSP) increased the sensitivity of tumor cells to hyperthermal intraperitoneal chemotherapy (HIPEC) and reduces the toxic and genotoxic effect of cisplatin (CIS) on normal cells without affecting its cytotoxicity on tumor cells (45). Adding WSP to chemotherapy increased the survival rate of mice by $160.3 \%$.

While propolis helps cancer treatments such as chemotherapy and radiotherapy, it also prevents the damage these treatments can cause to healthy cells (46). In an in vitro experiment with WSP, it was seen that WSP changed the tumoricidal activity of macrophages, increased the production of lymphocyte-activating factors, inhibited the human cervical carcinoma cell line and mouse lung fibroblast (V79) (47). In the study investigating the antitumor, genotoxic, chemopreventive and immunostimulatory effects of HIPEC with local chemoimmunotherapy in mice with Ehrlich acid tumor (EAT); mice were injected with $50 \mathrm{mg} / \mathrm{kg}$ WSP 3 and 7 days before implantation of EAT cells, and $5 \mathrm{mg} /$ $\mathrm{kg}$ CIS 3 days after. The combination of WSP + CIS provided inhibition of tumor growth. WSP application increased the cytotoxic effects of macrophages on tumor cells (45).

Propolis and its components such as chrysin, quercetin and CAPE increase the levels of cell cycle progression inhibitors such as p21, p27 and cyclins in vitro, and enables stopping of the cell cycle at different stages. In a study examining the in vitro antitumor activity of propolis ethanolic extract in human colon carcinoma HCT15 cells, dose- and time-dependent cytotoxic effects were observed (48). Its mechanism of action was explained as a decrease in glucose consumption and lactate production and modulation of glycolytic metabolism. 


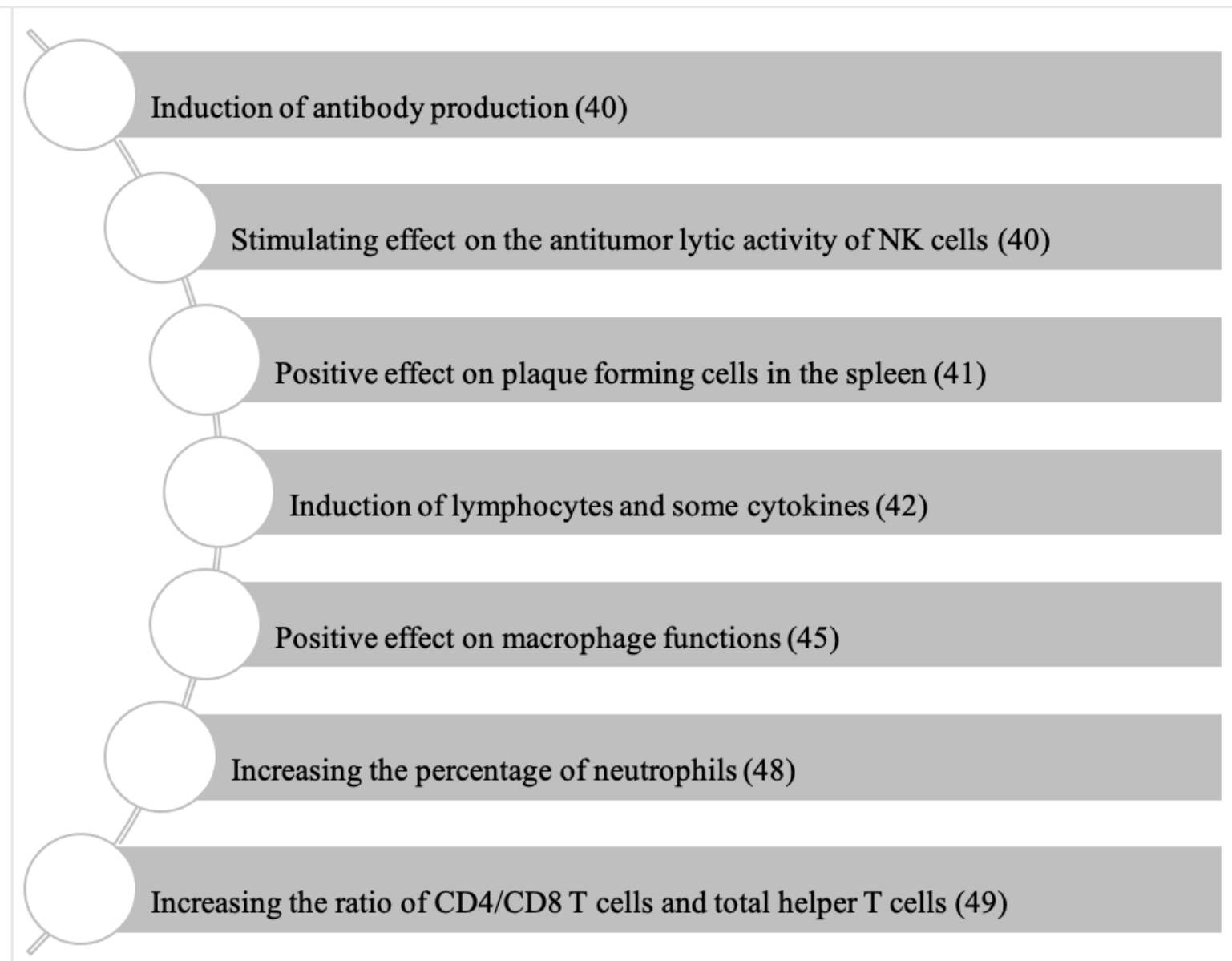

Figure 2. The role of propolis in cancer immunotherapy

Adding propolis to the anticancer drug irinotecan (IRI) treatment increases the antitumor activity of IRI (49). Compared to mice injected with EAT cells in the control group, the percentage of tumor cells in the peritoneal cavity was significantly reduced and the percentage of neutrophils was significantly higher in the experimental group treated with combined WSP and EEP. In a study in which $500 \mu \mathrm{g}$ artepilin C (3,5-diprenyl-4-hydroxycinnamic acid) obtained from Brazilian propolis was applied to human and murine malignant tumor cells three times a week. It was found that artepilin $\mathrm{C}$ showed cytotoxic effects and inhibited the growth of tumor cells in vitro and in vivo (50). The cytotoxic effects of artepilin $\mathrm{C}$ are most pronounced in carcinoma and malignant melanoma. In addition to the suppression of tumor growth, artepilin $\mathrm{C}$ also increased the ratio of CD4/CD8 $\mathrm{T}$ cells and total helper T-cells. These findings show that artepilin $\mathrm{C}$ has antitumor activity and activates the immune system.

All these studies have shown that propolis has a direct regulatory effect on the basic functional properties of immune cells (Figure 2). Therefore; propolis, a bee product, is a potent and natural anti-inflammatory agent that affects different types of immune response via immunoregulatory T-cells.

\section{Conclusion}

Propolis shows its important effects on the immune system with tumor-specific immunity. Propolis can increase the expression of immune system cells as well as increase the effects of these cells on the tumor. At the same time, it can direct immune system cells to tumor cells that can escape recognition by the immune system with certain mechanisms. According to the findings obtained from in vitro, in vivo and clinical studies; Propolis shows its immunotherapeutic effects on cancer cases as well as preventing the formation of cancer. Therefore; More clinical studies are needed on propolis indications and usage doses.

Peer-review: Externally peer reviewed.

\section{Authorship Contributions}

Concept: N.İ, B.P, A,G,B., Design: N.İ, B.P, A,G,B., Data Collection or Processing: N.İ, B.P. Analysis or Interpretation: N.İ, B.P, A,G,B., Literature Search: N.İ, B.P., Writing: N.İ, B.P, A,G,B.

Conflict of Interest: No conflict of interest was declared by the authors.

Financial Disclosure: The authors declared that this study received no financial support. 


\section{References}

1. Aydoğan F, Uygun K. Kanser hastalarında palyatif tedaviler. Klinik Gelişim 2011;24:4-9.

2. Mollanoori H, Shahraki H, Rahmati Y, Teimourian S. CRISPR/Cas9 and CAR-T cell, collaboration of two revolutionary technologies in cancer immunotherapy, an instruction for successful cancer treatment. Hum Immunol 2018;79:876-82.

3. Kiesgen S, Chicaybam L, Chintala NK, Adusumilli PS. Chimeric antigen receptor (CAR) T-cell therapy for thoracic malignancies. J Thorac Oncol 2018;13:16-26.

4. Gök Ö, Aslan A. Personalized Antigen Receptor with Cell Therapy (CAR-T) Journal of the Institute of Science and Technology 2019;9:2235-245.

5. Onur E, Nalbantsoy A, Kışla D. Immunotherapy and potential use of propolis in cancer immunotherapy. Food And Health 2018;4:231-46.

6. Yokuş B, Çakır DÜ. Cancer biochemistry. Dicle Üniv Vet Fak Derg 2012;1:7-18.

7. Gürbüz K. N Antimutajenler ve antikarsinojenler (kanser gelişiminin kimyasal bileşiklerle önlenmesi. Turkiye Klinikleri Journal Of Medical Sciences 2006;26:312-8.

8. Weinstein JN, Collisson EA, Mills GB, Shaw KRM, Ozenberger BA, Ellrott, $\mathrm{K}$, et al. The cancer genome atlas pan-cancer analysis project. Nature Genetics 2013;45:1113.

9. Coleman MP, Esteve J, Damiecki P, Arslan A, Renard H. Trends in cancer incidence and mortality. IARC Sci Publ 1993;121:1-806.

10. Yıldırım YK, Fadıloğlu Ç, Uyar M. Complementary Therapies In Palliative Cancer Care. Ağrı Dergisi 2006;18:26-32.

11. American Cancer Society. How Immunotherapy Is Used to Treat Cancer 2016. Retrieved November 25, 2019, Available from: URL: https://www.cancer.org/treatment/ treatments-and-side-effects/treatment- types/immunotherapy/whatis-immunotherapy.html

12. Abbott M, Ustoyev Y. Cancer and the immune system: the history and background of immunotherapy. Semin Oncol Nur 2019;35:150923.

13. Ekşioğlu Demiralp E, Ucuncu Kefeli A, Atasoy B. Radyoterapinin ve immnüterapinin birlikte kullanımı. Turkiye Klinikleri J Radiat Oncol-Special Topics 2015;1:34-40.

14. Aslan G. Tümör İmmünolojisi. Turk J Immunol 2010;15:713.

15. Abbas AK, Lichtman AH. Temel immunoloji, immun sistemin fonksiyonları ve bozuklukları (Y. Camığlu ve G. Deniz. Çeviri Ed.). İstanbul Medikal Yayıncılık 2007;179-83.

16. Özlük AA, Güner Oytun M, Günenç D. Kanser immünoterapisi. FNG \& Bilim Tip Transplantasyon Dergisi 2017;2:21-3.

17. Güney BC, Allahverdiyev DAM. Akciğer kanserinin NK hücre temelli immunoterapisi (dissertation).Yıldız Teknik Üni. 2018.

18. Bateman AC. Molecules in cancer immunotherapy: benefits and side effects. J Clin Pathol 2019;72:20-4.

19. American Cancer Society Cancer vaccines 2015. Retrieved November 28, 2019, Available from: URL: https://www.cancer.org/treatment/treatmentsand-side-effects/treatment-types/immunotherapy/cancer-vaccines.html
20. Perica K, Varela JC, Oelke M, Schneck J. Adoptive T Cell Immunotherapy for Cancer. Rambam Maimonides Med J 2015;6:e0004.

21. Sezgin C. Kanserde bitkilerle tedavide örnek uygulamalar. Çekin M. D., Altuncan F., Yakut A., Tinmaz M. Z. editors, Bitkilerle Tedavi Sempozyumu; 2010 Mayıs 6-10, Merkezefendi Geleneksel Tip Derneği, p.73-78.

22. Güneş Bayır A, Aksoy A, Koçyiğit A. The importance of polyphenols as functional food in health. Bezmialem Science 2019;7:157-63.

23. Barbaros B, Dikmen M. Cancer Immunotherapy. Erciyes Üniversitesi Fen Bilimleri Enstitüsü Dergisi 2015;31:177-81.

24. Pietta PG, Gardana C, Pietta AM. Analytical methods for quality control of propolis. Fitoterapia 2002 73:7-20.

25. Dündar E, Yıldırım HK. Factors Affecting Of Diversity Of Propolis. Arıcılık Araştırma Dergisi 2018;10:61-6.

26. Castaldo S, Capasso F. Propolis, an old remedy used in modern medicine. Fitoterapia 2002;73:1-6.

27. Banskota AH, Tezuka Y, Kadota S. Recent progress in pharmacological research of propolis. Phytother Res 2001;15:561-71.

28. Burdock GA. Review of the biological properties and toxicity of bee propolis. Food Chem Toxicol 1998;36:347-63.

29. Şahinler N. Propolisin Gelişimi Ve Kullanma Olanakları. MKÜ Ziraat Fakültesi Dergisi 1999; 169.

30. Badria F, Fathy H, Fatehe A, Elimam D, Ghazy M. Evaluate the cytotoxic activity of honey, propolis, and bee venom from different localities in Egypt against liver, breast, and colorectal cancer. J Apither 2017;2:1-4.

31. Albayrak S, Albayrak S. Propolis: Doğal Antimikrobiyal Madde. Ankara Eczacilık Fakültesi Dergisi 2008;37:201-15.

32. Kujumgiev A, Tsvetkova I, Serkedjieva Y, Bankova V, Christov R, Popov S. Antibacterial, antifungal and antiviral activity of propolis of different geographic origin. J Ethnopharmacol 1999;64:235-40.

33. Silici S. Investigation of biologically active components in propolis samples from different botanical origin. Erciyes Üniversitesi Fen Bilimleri Enstitüsü Fen Bilimleri Dergisi 2008;24:120-8.

34. Uzel A, Sorkun K, Onçağ O, Coğulu D, Gençay O, Salih B. Chemical compositions and antimicrobial activities of four different Anatolian propolis samples. Microbiol Res 2005;160:189-95.

35. Demir S, Aliyazicioglu Y, Turan I, Misir S, Mentese A, Yaman SO, et al. Antiproliferative and proapoptotic activity of Turkish propolis on human lung cancer cell line. Nutr Cancer 2016;68:165-72.

36. Al-Hariri M. Immune's-boosting agent: Immunomodulation potentials of propolis. J Family Community Med 2019;26:57-60.

37. Yonar SM, Ural MŞ, Silici S, Yonar ME. Malathion-induced changes in the haematological profile, the immune response, and the oxidative/antioxidant status of Cyprinus carpio carpio: protective role of propolis. Ecotoxicol Environ Saf 2014;102:202-9.

38. Polat G, Koçan D. Propolis ve Antimikrobiyel Etkisi. Türkiye 9. Gıda Kongresi; 2006, 24-26 Mayıs, Bolu-Türkiye.

39. Seven İ, Aksu T, Tatlı even P. Propolis and its Usage in Animal Nutrition. YYÜ VET FAK DERG 2007;18:79-84. 
40. Patel S. Emerging Adjuvant Therapy for Cancer: Propolis and its Constituents. J Diet Suppl 2016;13:245-68.

41. Meneghelli C, Joaquim LS, Félix GL, Somensi A, Tomazzoli M, da Silva DA, et al. Southern Brazilian autumnal propolis shows antiangiogenic activity: an in vitro and in vivo study. Microvasc Res 2013;88:1-11.

42. Sforcin JM. Propolis and the immune system: a review. J Ethnopharmacol 2007;113:1-14.

43. Cuesta A, Rodríguez A, Esteban MA, Meseguer J. In vivo effects of propolis, a honeybee product, on gilthead seabream innate immune responses. Fish Shellfish Immunol 2005;18:71-80.

44. Ivanovskaa ND, Dimov VB, Pavlovaa S, Bankova VS, Popov SS. Immunomodulatory action of propolis. V. Anticomplementary activity of a water-soluble derivative. J Ethnopharmacol 1995;47:135-43.

45. Oršolić N, Car N, Lisičić D, Benković V, Knežević AH, Đikić D, Petrik J. Synergism between propolis and hyperthermal intraperitoneal chemotherapy with cisplatin on ehrlich ascites tumor in mice. J Pharm Sci 2013;102:4395-405.
46. Sforcina JM, Bankovab V. (Propolis: Is there a potential for the development of new drugs? J Ethnopharmacol 2011;133:253-60.

47. Orsolic N, Sver L, Terzic S, Basic I. Peroral application of watersoluble derivative of propolis (WSDP) and its related polyphenolic compounds and their influence on immunological and antitumor activity. Vet Res Commun 2005;29:575-93.

48. Valença I, Morais-Santos F, Miranda-Gonçalves V, Ferreira PM, Almeida-Aguiar C, Baltazar F. Portuguese propolis disturbs glycolytic metabolism of human colorectal cancer in vitro. BMC Complement Altern Med 2013;13:184.

49. Lisičić D, Benković V, Đikić D, Blažević AS, Mihaljević J, Oršolić N, Knežević AH. Addition of propolis to irinotecan therapy prolongs survival in ehrlich ascites tumor-bearing mice. Cancer Biother Radiopharm 2014;29:62-9.

50. Kimoto T, Arai S, Kohguchi M, Aga M, Nomura Y, Micallef MJ, et al. Apoptosis and suppression of tumor growth by artepillin $\mathrm{C}$ extracted from Brazilian propolis. Cancer Detect Prev 1998;22:506-15. 